\title{
Short communication: Effects of supplementation with pomegranate seed pulp on concentrations of conjugated linoleic acid and punicic acid in goat milk
}

\author{
J. Modaresi, ${ }^{*}$ M. H. Fathi Nasri, ${ }^{*}$ L. Rashidi, $†$ O. Dayani, $\ddagger$ and E. Kebreab $\S^{1}$ \\ *Department of Animal Science, University of Birjand, Birjand, Iran \\ †Institute of Standard and Industrial Research of Iran, Karaj, Iran \\ ‡Department of Animal Science, Shahid Bahonar University of Kerman, Kerman, Iran \\ $\S$ Department of Animal Science, University of California, Davis 95616
}

\section{ABSTRACT}

The effects of feeding pomegranate seed pulp (PSP) on milk yield, milk composition, fatty acid profiles of milk fat, and blood metabolites were examined in this study. During a pretrial period, 27 multiparous southern Khorasan (Iran) cross-bred goats were fed a similar diet and dry matter intake, milk yield, and milk composition were recorded. After adaptation and based on pretrial records, the goats were randomly assigned to 1 of 3 experimental diets and were housed in individual stalls. Experimental diets included 0, 6, or 12\% of PSP (dry matter basis) and were fed as total mixed rations ad libitum for a 45-d period. Diets were formulated to be isonitrogenous and isocaloric. Supplementation of PSP did not affect dry matter intake or average daily gain of goats. Milk yield was not affected by inclusion of PSP in the diet. Milk fat concentration of goats fed diets with 6 and 12\% PSP increased, but milk fat yield, milk protein concentration, and milk solids-notfat concentration of goats were not affected by diets. Feeding PSP did not affect blood glucose, cholesterol, urea N, triglyceride, or lipoproteins. Feeding goats a diet containing $12 \%$ PSP modified the milk fatty acid profile, including conjugated linoleic, punicic, and vaccenic acids.

Key words: conjugated linoleic acid, goat milk, pomegranate seed pulp, punicic acid

\section{Short Communication}

Fatty acid (FA) composition is an important component of the nutritional quality of milk. Different FA are involved as positive or negative predisposing factors for human health (Chilliard et al., 2003; Luna et al., 2008). The term "conjugated FA" is a generic name for po-

Received December 6, 2010.

Accepted April 14, 2011.

${ }^{1}$ Corresponding author: ekebreab@ucdavis.edu sitional and geometric isomers of polyunsaturated FA with conjugated double bonds (Bauman et al., 2001). The cis-9,trans-11 conjugated linoleic acid (CLA) is the main CLA isomer present in milk and has been reported to have anticarcinogenic, antiatherogenic, and antidiabetic (type II) properties (Lee et al., 2005; Moon et al., 2008). Fat supplementation of dairy goat diets has potential for changing milk yield, fat content, and FA profile (Chilliard et al., 2003).

Pomegranate (Punica granatum L.) belongs to the Punicaceae family and it is one of the oldest known edible fruits (Seeram et al., 2006). The edible part of the pomegranate (aril) is about 55 to $60 \%$ of total fruit weight and consists of about 75 to $85 \%$ juice and 15 to $25 \%$ seeds. Pomegranate seed pulp (PSP) is a by-product of the industrial decoction of pomegranate and contains large amounts of oil, with some Iranian varieties having total lipid contents ranging from 6.6 to $19.3 \%$ (DM basis; Abbasi et al., 2008). Pomegranate seed oil consists of 65 to $80 \%$ conjugated FA, the most important of which is cis-9,trans-11,cis-13 octadecatrienoic acid, also called punicic acid (Abbasi et al., 2008). Punicic acid is metabolized to cis-9,trans-11 CLA via a saturation mechanism (Tsuzuki et al., 2006). Because of high punicic acid content, PSP may be used as dietary supplement to increase CLA and punicic acid concentrations of milk fat. To our knowledge, no published studies have evaluated pomegranate oil or pomegranate by-products on milk FA profile of goats. The hypothesis is that because PSP contains a considerable amount of oil, the milk FA profile may be altered. Therefore, the objective of this study was to investigate the effect of PSP supplementation on performance and specifically on milk FA profile including conjugated polyunsaturated FA, CLA isomers, and punicic acid content in southern Khorasan cross-bred goats.

All procedures for this trial were conducted according to the guidelines of the Iranian Council of Animal Care (1995). Twenty-seven multiparous southern Khorasan cross-bred goats in mid lactation (average DIM of 71 
Table 1. Ingredients, nutrient composition, and fatty acid profile of the experimental diets

\begin{tabular}{|c|c|c|c|}
\hline \multirow[b]{2}{*}{ Item } & \multicolumn{3}{|c|}{$\operatorname{Diet}^{1}$} \\
\hline & Control & LPSP & HPSP \\
\hline \multicolumn{4}{|l|}{ Ingredients, $\%$ of DM } \\
\hline Alfalfa hay & 40.0 & 40.0 & 40.0 \\
\hline Barley grain, ground & 12.0 & 9.0 & 6.0 \\
\hline Corn grain, ground & 32.7 & 29.7 & 26.7 \\
\hline Soybean meal & 12.6 & 12.6 & 12.6 \\
\hline Pomegranate seed pulp ${ }^{2}$ & 0 & 6.0 & 12.0 \\
\hline Sodium bicarbonate & 0.9 & 0.9 & 0.9 \\
\hline Vitamin and mineral mixture $^{3}$ & 0.6 & 0.6 & 0.6 \\
\hline Dicalcium phosphate & 0.6 & 0.6 & 0.6 \\
\hline Calcium carbonate & 0.3 & 0.3 & 0.3 \\
\hline Sodium chloride & 0.3 & 0.3 & 0.3 \\
\hline \multicolumn{4}{|l|}{ Nutrients $^{4}$} \\
\hline DM, \% & $94.3(94.5)$ & $94.3(94.6)$ & $94.2(94.5)$ \\
\hline ME, Mcal/kg of DM & $2.6(2.4)$ & $2.6(2.5)$ & $2.5(2.3)$ \\
\hline $\mathrm{CP}, \%$ of DM & $15.3(14.5)$ & $15.1(14.0)$ & $15.3(13.9)$ \\
\hline RUP, $\%$ of DM & $2.9(2.5)$ & $3.3(2.6)$ & $3.2(2.5)$ \\
\hline $\mathrm{RDP}, \%$ of DM & $12.3(12.0)$ & $11.8(11.4)$ & $12.1(11.3)$ \\
\hline Ether extract, $\%$ of DM & $2.2(2.0)$ & $2.5(2.1)$ & $3.2(3.1)$ \\
\hline $\mathrm{NDF}, \%$ of DM & $26.9(27.7)$ & $28.2(28.9)$ & $29.9(30.5)$ \\
\hline $\mathrm{ADF}, \%$ of $\mathrm{DM}$ & $19.9(20.9)$ & $21.0(21.7)$ & $22.0(23.1)$ \\
\hline NFC, $\%$ of DM & $45.8(44.9)$ & $44.8(44.6)$ & $41.7(41.5)$ \\
\hline Ash, \% of DM & $9.8(10.9)$ & $9.4(10.4)$ & $9.9(11.0)$ \\
\hline $\mathrm{Ca}, \%$ of $\mathrm{DM}$ & $0.83(0.86)$ & $0.89(0.92)$ & $0.91(0.92)$ \\
\hline $\mathrm{P}, \%$ of $\mathrm{DM}$ & $0.53(0.49)$ & $0.52(0.50)$ & $0.50(0.46)$ \\
\hline \multicolumn{4}{|l|}{ Fatty acids, $\%$ of total fatty acids } \\
\hline $\mathrm{C} 12: 0$ & 0.02 & 0.02 & 0.02 \\
\hline C14:0 & 0 & 0 & 0 \\
\hline C16:0 & 0.51 & 0.53 & 0.55 \\
\hline C18:0 & 0.26 & 0.28 & 0.29 \\
\hline $\mathrm{C} 18: 2$ & 1.13 & 1.11 & 1.10 \\
\hline $\mathrm{C} 18: 3^{5}$ & 0.21 & 0.21 & 0.21 \\
\hline cis-9,trans-11,cis-13 18:3 (punicic acid) & 0 & 0.56 & 1.12 \\
\hline $\mathrm{C} 20: 0$ & 0.01 & 0.01 & 0.02 \\
\hline
\end{tabular}

${ }^{1}$ Control, LPSP, and HPSP diets contained 0, 6, 12\% (DM basis) pomegranate seed pulp, respectively.

${ }^{2}$ Chemical composition (DM basis): gross energy $=3.96 \mathrm{Mcal} / \mathrm{kg}, \mathrm{CP}=8.85 \%(\mathrm{RDP}=77 \%, \mathrm{RUP}=23 \%)$, ether extract $=12.5 \%, \mathrm{ADF}=31.1 \%, \mathrm{NDF}=43.5 \%, \mathrm{NFC}=26.9 \%$, ash $=9.2 \%, \mathrm{Ca}=1.73 \%, \mathrm{P}=0.22 \%$.

${ }^{3}$ One kilogram of vitamin and mineral mixture contained $140 \mathrm{~g}$ of $\mathrm{Ca} ; 70 \mathrm{~g}$ of Na; $70 \mathrm{~g}$ of $\mathrm{P} ; 20 \mathrm{~g}$ of $\mathrm{Mg} ; 2.4 \mathrm{~g}$ of Fe; $2.4 \mathrm{~g}$ of $\mathrm{Zn} ; 2.6 \mathrm{~g}$ of $\mathrm{Mn} ; 0.24 \mathrm{~g}$ of $\mathrm{Cu} ; 0.0001 \mathrm{~g}$ of Se; $0.1 \mathrm{~g}$ of Co; $0.1 \mathrm{~g}$ of I; 400,000 IU of vitamin A; $100,000 \mathrm{IU}$ of vitamin $\mathrm{D}_{3}$; and $100 \mathrm{IU}$ of vitamin $\mathrm{E}$, and $3 \mathrm{~g}$ of beta-hydroxytoluene.

${ }^{4}$ The values in parentheses are the nutrient composition of feed residues.

${ }^{5}$ Except punicic acid.

\pm 12.5 , average daily milk yield of $1.09 \pm 0.13 \mathrm{~kg}$, and average BW of $28 \pm 2.5 \mathrm{~kg}$ ) were housed in individual stall barns for $10 \mathrm{~d}$ and fed a similar diet for barn adjustment and collection of pretrial records. At the onset of the 45-d trial, goats were grouped according to pretrial milk yield and then randomly assigned to 1 of the 3 experimental diets. Goats in each group were fed individually a TMR ad libitum. All diets consisted of $40 \%$ alfalfa hay and 60\% concentrate (DM basis). Dietary treatments were supplemented with PSP (DM basis) at $0 \%$ (control), $6 \%$ (low PSP, LPSP), or $12 \%$ (high PSP, HPSP) levels. The ingredients, chemical composition, and FA composition of the experimental diets are given in Table 1. Diets were formulated to be isonitrogenous and isoenergetic and met NRC (2007) recommendations. Clean water and vitamin-mineral blocks were freely available for all animals.

Goats were fed 3 times a day at 0700, 1200, and $1830 \mathrm{~h}$. Samples of diets were collected weekly and voluntary feed intake was registered daily. Goats were milked twice daily at 0530 and $1730 \mathrm{~h}$, and milk yield was recorded daily. Milk samples $(60 \mathrm{~mL})$ were collected at each milk yield recording and analyzed for fat, protein, lactose, and SNF. In wk 2, 4, and 6 of the trial period, additional milk samples were taken and frozen at $-20^{\circ} \mathrm{C}$ for later analysis of FA profile. At the start of the experiment, goats were free from clinical mastitis. Blood samples were collected on d 1, 15, 30, and 45 of the experimental period at $0830 \mathrm{~h}$. Samples from the jugular vein were collected into evacuated blood 
collection tubes (Improve, Guangzhou Improve Medical Instruments Co. Ltd., Guangzhou, Guangdong, China), which contained heparin as an anticoagulant. After collecting a $10-\mathrm{mL}$ blood sample from each goat, the sample was centrifuged for $15 \mathrm{~min}$ at 3,000 $\times \mathrm{g}$ to separate the plasma, which was then frozen at $-25^{\circ} \mathrm{C}$ until it was analyzed for metabolites.

Feed samples were ground in a mill (1-mm screen; Type 3100, Perten, Helsinki, Finland) and the DM content was determined by oven drying (Behdad oven, Behdad Co., Tehran, Iran) at $105^{\circ} \mathrm{C}$ for $24 \mathrm{~h}$. Crude protein content was determined according to the Kjeldahl method (AOAC, 1990) by using a Gerhardt analyzer (model VAP 50/OT, Gerhardt, Königswinter, Germany). The NDF and ADF contents were determined according to Van Soest et al. (1991) using $\alpha$-amylase and sodium sulfite. Ash content was determined according to AOAC (1990) by using the electronic oven (model EF 11/88, Lenton, Sheffield, UK) and fat content was determined by using a soxhlet Gerhardt (model SE 416, Gerhardt). Analysis of the FA content of the feeds was performed according to ISIRI (1997). Milk fat, protein, lactose, and SNF were measured with a MilkoScan Foss Electric S-50 (Foss Electric, Hillerød, Denmark). For analysis of milk FA, milk fat was extracted following the Bouattour et al. (2008) method. Based on this method, milk was immediately cooled after milking and the fat fraction was separated by centrifugation for $30 \mathrm{~min}$ at $6,000 \times g$ and $4^{\circ} \mathrm{C}$, and then stored at $-20^{\circ} \mathrm{C}$. Milk FA were analyzed after extraction of milk fat samples and methylation (ISIRI, 1997). Briefly, $0.1 \mathrm{~g}$ of the extracted milk fat was mixed with $2 \mathrm{~mL}$ of $1 M \mathrm{KOH}$ and $5 \mathrm{~mL}$ of $14 \%$ boron trifluoride in methanol. The sample was methylated by incubation at $100^{\circ} \mathrm{C}$ for $60 \mathrm{~min}$ and, after cooling to room temperature, extracted with $5 \mathrm{~mL}$ of hexane. The FA methyl esters in the hexane layer were analyzed by a gas chromatograph (3400 Varian Star; Varian Inc., Palo Alto, CA). In this method, CP-SIL-88 capillary columns were used and helium was the carrier gas. Column temperature was initially $50^{\circ} \mathrm{C}$ for $1 \mathrm{~min}$, increasing by $10^{\circ} \mathrm{C} / \mathrm{min}$ to $190^{\circ} \mathrm{C}$, and was then held at $190^{\circ} \mathrm{C}$ for $130 \mathrm{~min}$. The temperature of the injector was $270^{\circ} \mathrm{C}$, and that of the detector was $300^{\circ} \mathrm{C}$. Peaks were identified by comparing their retention times with those of an authentic standard FA methyl ester mixture (Sigma-Aldrich Co., St. Louis, MO). A pomegranate seed oil reference standard was used as a routine quality control and as a check for recoveries and correction factors for punicic acid (ISIRI, 1997). Blood samples were centrifuged $(3,000 \times g$ for $15 \mathrm{~min})$, and plasma frozen at $-20^{\circ} \mathrm{C}$ for later analysis. Plasma levels of lowdensity lipoprotein cholesterol, high-density lipoprotein cholesterol, triglyceride, urea N, cholesterol, and glucose were determined using Parsazmun Liquid Test kits
(Parsazmun Co., Karaj, Iran) and a spectrophotometer (Secomam XS2, Secomam Co., Ales, France).

Data were analyzed using the MIXED procedure of SAS (SAS Institute, Cary, NC) for repeated measurements. The statistical model was $y_{i j k l}=\mu+T_{i}+A_{j(i)}$ $+W_{k}+T_{i} \times W_{k}+e_{i j k l}$, where $\mu$ is the overall mean, $T_{i}$ is the fixed effect of treatments, $A_{j(i)}$ is the random effect of $j$ th goat within ith diet, $W_{k}$ is the fixed effect of repeated measurements, $T_{i} \times W_{k}$ is the interaction between $T_{i}$ and $W_{k}$, and $e_{i j k l}$ is the residual error. Significant differences were declared at $P<0.05$ and results are presented as treatment means with SEM.

Total lipid contents of LPSP and HPSP diets were higher compared with that of control. Dry matter intake and milk yield of goats were not affected by diets (Table 2). Furthermore, feeding PSP did not affect FCM yield, ADG, or production efficiency. Although dietary fat supplementation to mid-lactation dairy cows often increases milk yield, this is not the case in goats and ewes (Mir et al., 1999), in agreement with our observations. Feeding PSP increased milk fat concentration $(P$ $<0.05)$ but milk fat yield was not affected. Milk protein concentration, milk protein yield, milk SNF concentration, and milk SNF yield of goats were not affected by treatment. Although fat supplementation in dairy cows and sheep diets often decreases milk protein content, Chilliard et al. (2003) and Nudda et al. (2006) reported no effect in goats, which was in agreement with our results. Milk lactose concentration increased with PSP supplementation. Indirect comparisons with studies in cows show that plant oils increase milk lactose concentrations in goats but not in cows, and highlight the possibility of differences in the regulation of mammary lactose synthesis between ruminant species (Bernard et al., 2009).

Diets containing PSP altered milk fat composition. Goat milk fatty acid profile is shown in Table 3. The inclusion of PSP in the diets did not substantially change the concentration of FA from C4:0 to C10:0. Chilliard et al. (2003) and Chilliard and Ferlay (2004) also reported no changes in $\mathrm{C} 4: 0$ to $\mathrm{C} 8: 0$ milk fat contents after lipid supplementation with several types of basal diets enriched with polyunsaturated FA. The lack of change could be partly because short-chain FA are synthesized by metabolic pathways that are independent of acetyl-CoA carboxylase (Chilliard and Ferlay, 2004). Treatments did not influence the concentration of milk saturated FA from C10:0 to C16:0, possibly because of specific characteristics of FA metabolism in the goat mammary gland. In contrast to findings in dairy cows, enzymes involved in pathways of de novo lipogenesis in goat mammary gland seem less affected by lipid supplementation with polyunsaturated FA (Luna et al., 2008). The inclusion of $12 \%$ PSP in the 
Table 2. Daily intake, milk yield, milk composition, and ADG of goats as affected by diet

\begin{tabular}{|c|c|c|c|c|c|}
\hline \multirow[b]{2}{*}{ Item } & \multicolumn{3}{|c|}{ Diet $^{1}$} & \multirow[b]{2}{*}{ SEM } & \multirow[b]{2}{*}{$P$-value } \\
\hline & Control & LPSP & HPSP & & \\
\hline DMI, g/d & 1,724 & 1,736 & 1,722 & 14.3 & NS \\
\hline \multicolumn{6}{|l|}{ Yield, g/d } \\
\hline Milk & 1,057 & 988 & 984 & 22.6 & NS \\
\hline Milk, $4 \%$ FCM $^{2}$ & 1,071 & 1,099 & 1,109 & 26.1 & NS \\
\hline Milk fat & 43.2 & 46.9 & 47.7 & 1.77 & NS \\
\hline Milk protein & 39.5 & 36.2 & 36.2 & 1.21 & NS \\
\hline Milk lactose & 42.7 & 41.3 & 45.4 & 1.81 & NS \\
\hline Milk SNF & 103 & 93.0 & 95.0 & 3.40 & NS \\
\hline \multicolumn{6}{|c|}{ Concentration, $\%$ of milk } \\
\hline Milk fat & $4.1^{\mathrm{b}}$ & $4.7^{\mathrm{a}}$ & $4.8^{\mathrm{a}}$ & 0.12 & ** \\
\hline Milk protein & 3.8 & 3.7 & 3.6 & 0.04 & NS \\
\hline Milk lactose & $4.1^{\mathrm{b}}$ & $4.2^{\mathrm{ab}}$ & $4.3^{\mathrm{a}}$ & 0.03 & $* *$ \\
\hline Milk SNF & 9.7 & 9.6 & 9.6 & 0.11 & NS \\
\hline Total ADG, g/d & 106 & 74 & 96 & 13.6 & NS \\
\hline Production efficiency ${ }^{3}$ & 0.62 & 0.63 & 0.64 & 0.17 & NS \\
\hline
\end{tabular}

diet reduced the concentration of $\mathrm{C} 16: 1$ in goat milk fat $(P<0.05)$ compared with control diet. The content of C16:1 in milk originates both from de novo synthesis in the mammary gland and from arterial blood uptake (Nudda et al., 2006). In the HPSP diet, the reduction of C16:1 was probably due to decreased synthesis in the mammary gland, because the index of $\Delta^{9}$-desaturase activity was higher in the control group. A similar trend has been observed with other oil sources (Chilliard et al., 2003). The HPSP diet increased the concentrations of $c i s-12$ C18:1, but feeding PSP decreased cis-11 C18:1 concentration and did not influence cis-9 $\mathrm{C} 18: 1$ or cis13 C18:1 contents of milk fat (Table 3). The concentration of trans-11 C18:1 (vaccenic acid) in milk fat was increased by feeding the HPSP diet. Although the predominant biohydrogenation end-product of unsaturated FA in the rumen is stearic acid, several monounsaturated intermediates such as vaccenic acid are often generated (Palmquist et al., 2005) and subsequently found in milk. Both $\alpha$-linolenic and linoleic acids are precursors of vaccenic acid in the rumen (Nudda et al., 2006). Increases in vaccenic acid in milk fat caused increased endogenous synthesis of total CLA and cis9,trans-11 CLA in the mammary gland; therefore, supplementation with $12 \%$ PSP was also an effective means of increasing the concentration of cis-9,trans-11 CLA in milk fat of goats. This result is in agreement with other studies that supplemented diets with extruded linseed cake and whole linseed (sources rich in linolenic acid), and reported an increased concentration of total CLA and cis-9,trans-11 CLA in goat milk fat
(Nudda et al., 2006). Feeding PSP did not influence the trans-10,cis-12 CLA and trans-8,cis-10 CLA contents of milk fat. According to Bouattour et al. (2008), trans10,cis-12 CLA remains at trace levels in goat milk. The milk content of C18:3 n-3, which contributes to prevention of atherosclerosis in humans (Kris-Etherton and $\mathrm{Yu}, 1997)$, increased $(P<0.05)$ in goats fed the HPSP diet compared with the control. According to Chilliard et al. (2003), linseed oil (rich in C18:3) had a positive effect on the proportion of milk linolenic acid; in our study, PSP increased $(P<0.05)$ the proportion of cis-9,trans-12 C18:2 and trans-9,cis-12 C18:2. Although the LPSP diet did not increase the concentration of punicic acid in milk fat, supplementation with $12 \%$ PSP was an effective means of increasing the concentration $(P<0.001)$ of this important FA. This could be attributed to partial escape of punicic acid from the rumen before biohydrogenation to stearic acid, and subsequent secretion in milk fat. Supplementation with $12 \%$ PSP was also an effective means of increasing C18:3 n-3 in milk fat $(P<0.001)$, mainly because the PSP used in the study contained $75 \%$ punicic acid. The desaturase indexes were not modified for C14:0 and C18:0, but were decreased $(P<0.05)$ for $\mathrm{C} 16: 0$ when PSP was fed. Substantial reductions in desaturase index for C16:0 have been associated with a decrease in mammary palmitoyl-CoA desaturase mRNA abundance and activity (Bernard et al., 2009).

Diet had no effect on plasma glucose, triglyceride, high-density lipoprotein concentrations, or total cholesterol. Yamasaki et al. (2006) also found no effect 
Table 3. Milk fatty acid (FA) profile (\% of total FA methyl esters) of goats as affected by diets

\begin{tabular}{|c|c|c|c|c|c|}
\hline \multirow[b]{2}{*}{ Fatty acid } & \multicolumn{3}{|c|}{ Diet $^{1}$} & \multirow[b]{2}{*}{ SEM } & \multirow[b]{2}{*}{$P$-value } \\
\hline & Control & LPSP & HPSP & & \\
\hline $4: 0$ & 1.28 & 1.43 & 1.48 & 0.058 & NS \\
\hline $5: 0$ & - & 0.1 & 0.15 & 0.050 & NS \\
\hline $6: 0$ & 1.81 & 2.07 & 2.16 & 0.124 & NS \\
\hline $8: 0$ & 2.52 & 2.87 & 2.87 & 0.156 & NS \\
\hline $8: 1$ & 0.13 & 0.13 & 0.14 & 0.034 & NS \\
\hline 10:0 & 10.08 & 10.57 & 10.78 & 0.303 & NS \\
\hline 10:1 & 0.44 & 0.45 & 0.42 & 0.029 & NS \\
\hline 12:0 & 5.33 & 5.00 & 4.94 & 0.192 & NS \\
\hline trans-12:1 & 0.15 & 0.14 & 0.18 & 0.255 & NS \\
\hline cis-12:1 & 0.30 & 0.21 & 0.30 & 0.248 & NS \\
\hline $14: 0$ & 10.22 & 10.31 & 9.85 & 0.305 & NS \\
\hline trans-14:1 & 0.19 & 0.17 & 0.17 & 0.018 & NS \\
\hline cis-14:1 & 0.39 & 0.32 & 0.32 & 0.038 & NS \\
\hline $15: 0$ & 1.36 & 1.26 & 1.12 & 0.017 & NS \\
\hline $15: 0$ & 0.29 & 0.24 & 0.27 & 0.026 & NS \\
\hline $16: 0$ & 29.65 & 31.91 & 29.20 & 1.001 & NS \\
\hline trans-16:1 & $0.54^{\mathrm{a}}$ & $0.45^{\mathrm{ab}}$ & $0.39^{\mathrm{b}}$ & 0.040 & $*$ \\
\hline cis-16:1 & $1.06^{\mathrm{a}}$ & $0.98^{\mathrm{a}}$ & $0.70^{\mathrm{b}}$ & 0.070 & $* *$ \\
\hline $17: 0$ & 1.01 & 0.92 & 0.98 & 0.094 & NS \\
\hline $17: 1$ & 0.45 & 0.33 & 0.37 & 0.062 & NS \\
\hline $17: 2$ & $0.28^{\mathrm{a}}$ & $0.21^{\mathrm{b}}$ & $0.18^{\mathrm{b}}$ & 0.015 & $* * *$ \\
\hline $18: 0$ & 6.87 & 6.88 & 7.85 & 0.513 & NS \\
\hline cis-9 18:1 & 17.09 & 15.95 & 16.39 & 0.508 & NS \\
\hline cis-11 18:1 & $0.44^{\mathrm{a}}$ & $0.32^{\mathrm{b}}$ & $0.34^{\mathrm{b}}$ & 0.020 & $* *$ \\
\hline cis-12 18:1 & $0.22^{\mathrm{b}}$ & $0.23^{\mathrm{b}}$ & $0.37^{\mathrm{a}}$ & 0.020 & $* * *$ \\
\hline cis-13 18:1 & 0.20 & 0.18 & 0.23 & 0.018 & NS \\
\hline cis-15 18:1 & $0.10^{\mathrm{a}}$ & $0.06^{\mathrm{b}}$ & $0.09^{\mathrm{ab}}$ & 0.0009 & $*$ \\
\hline trans-11 18:1 & $1.05^{\mathrm{b}}$ & $1.15^{\mathrm{b}}$ & $1.89^{\mathrm{a}}$ & 0.159 & $* *$ \\
\hline cis-14 18:1 + trans-16 18:1 & 0.09 & 0.06 & 0.08 & 0.009 & NS \\
\hline$($ cis -9, trans $-13+$ trans -8, cis -12$) 18: 2$ & 0.05 & 0.03 & 0.05 & 0.014 & NS \\
\hline cis-9,trans-12 18:2 & $0.19^{\mathrm{b}}$ & $0.20^{\mathrm{ab}}$ & $0.24^{\mathrm{a}}$ & 0.014 & $*$ \\
\hline trans-9,cis-12 18:2 & $0.18^{\mathrm{b}}$ & $0.18^{\mathrm{b}}$ & $0.25^{\mathrm{a}}$ & 0.013 & $* *$ \\
\hline cis-9,cis-15 18:2 & 0.05 & 0.05 & 0.04 & 0.013 & NS \\
\hline cis-9,trans-11 18:2 & $0.11^{\mathrm{b}}$ & $0.13^{\mathrm{b}}$ & $0.29^{\mathrm{a}}$ & 0.014 & $* *$ \\
\hline trans-10,cis-12 18:2 & 0.001 & 0.003 & 0.003 & 0.0010 & NS \\
\hline trans-8,cis-10 18:2 & 0.003 & 0.004 & 0.007 & 0.0014 & NS \\
\hline Total conjugated linoleic acids & $0.14^{\mathrm{b}}$ & $0.16^{\mathrm{b}}$ & $0.37^{\mathrm{a}}$ & 0.058 & $*$ \\
\hline $18: 2 \mathrm{n}-6$ & 2.61 & 2.36 & 2.42 & 0.114 & NS \\
\hline cis-9, cis-12,trans-15 18:3 & 0.09 & 0.08 & 0.04 & 0.023 & NS \\
\hline trans-9,cis-12,cis-15 18:3 & 0.07 & 0.05 & 0.06 & 0.008 & NS \\
\hline $18: 3 \mathrm{n}-3$ & $0.74^{\mathrm{b}}$ & $0.75^{\mathrm{b}}$ & $1.30^{\mathrm{a}}$ & 0.082 & $* * *$ \\
\hline cis-9,trans-11,cis-13 18:3 & $0.15^{\mathrm{b}}$ & $0.46^{\mathrm{b}}$ & $1.19^{\mathrm{a}}$ & 0.12 & $* * *$ \\
\hline $20: 0$ & 0.16 & 0.16 & 0.22 & 0.022 & NS \\
\hline $20: 1$ & 0.27 & 0.23 & 0.23 & 0.013 & NS \\
\hline $22: 0$ & - & 0.052 & 0.079 & 0.033 & NS \\
\hline $22: 1$ & $0.04^{\mathrm{b}}$ & $0.07^{\mathrm{b}}$ & $0.22^{\mathrm{a}}$ & 0.031 & $* * *$ \\
\hline $22: 6$ & $0.25^{\mathrm{a}}$ & $0.15^{\mathrm{b}}$ & $0.16^{\mathrm{ab}}$ & 0.029 & $*$ \\
\hline \multicolumn{6}{|l|}{ Desaturase index ${ }^{2}$} \\
\hline C14 & 0.05 & 0.04 & 0.04 & 0.004 & NS \\
\hline $\mathrm{C} 16$ & $0.05^{\mathrm{a}}$ & $0.04^{\mathrm{b}}$ & $0.04^{\mathrm{b}}$ & 0.009 & $* *$ \\
\hline $\mathrm{C} 18$ & 0.73 & 0.72 & 0.70 & 0.014 & NS \\
\hline
\end{tabular}

${ }^{\mathrm{a}, \mathrm{b}}$ Means within a row with different superscripts differ $(P<0.05)$.

${ }^{1}$ Control, LPSP, and HPSP diets contained 0, 6, and 12\% (DM basis) pomegranate seed pulp, respectively.

${ }^{2}$ Calculated for each fatty acid according to Bouattour et al. (2008) as (product of $\Delta^{9}$-desaturase)/(product of $\Delta^{9}$-desaturase + substrate of $\Delta^{9}$-desaturase); that is, for C14: C14:1/(C14:1 + C14:0), for C16: C16:1/(C16:1 $+\mathrm{C} 16: 0)$, and for C18: C18:1/(C18:1 + C18:0).

${ }^{*} P<0.05 ;{ }^{* *} P<0.01 ;{ }^{* * *} P<0.001$.

on total cholesterol in mice fed pomegranate seed oil. Bernard et al. (2009), however, reported higher total plasma cholesterol in goats fed diets supplemented with sunflower seed oil or linseed oils. These differences could be attributed to the type of fat and FA composition in
PSP and other fat sources. In conclusion, PSP could be used successfully as a replacement for cereal grains and other energy-rich dietary supplements because of its relatively high fat content. Supplementation of PSP, which is rich in punicic acid, altered milk FA profile in 
goats. Dietary PSP supplementation at a level of $12 \%$ was an effective means of increasing concentrations of punicic acid, cis-9,trans-11 CLA, C18:3 n-3, and total CLA in goat milk fat. Despite the adverse effect of some CLA on milk fat content (e.g., trans-10,cis-12 CLA), feeding PSP did not decrease milk fat concentration or yield.

\section{REFERENCES}

Abbasi, H., K. Rezaei, and L. Rashidi. 2008. Extraction of essential oils from the seeds of pomegranate using organic solvents and supercritical $\mathrm{CO}_{2}$. J. Am. Oil Chem. Soc. 85:83-89.

AOAC. 1990. Official Methods of Analysis. 15th ed. Vol. 1. Assoc. Offic. Anal. Chem., Arlington, VA.

Bauman, D. E., B. A. Corl, L. H. Baumgard, and J. M. Griinari. 2001. Conjugated linoleic acid (CLA) and the dairy cow. Pages 221-250 in Recent Advances in Animal Nutrition. P. C. Garnsworthy and J. Wiseman, ed. Nottingham University Press, Nottingham, UK.

Bernard, L., M. Bonnet, C. Leroux, K. J. Shingfield, and Y. Chilliard. 2009. Effect of sunflower-seed oil and linseed oil on tissue lipid metabolism, gene expression, and milk fatty acid secretion in alpine goats fed maize silage--based diets. J. Dairy Sci. 92:6083-6094.

Bouattour, M. A., R. Casals, E. Albanell, X. Such, and G. Caja. 2008. Feeding soybean oil to dairy goats increases conjugated linoleic acid in milk. J. Dairy Sci. 91:2399-2407.

Chilliard, Y., and A. Ferlay. 2004. Dietary lipids and forages interactions on cow and goat milk fatty acid composition and sensory properties. Reprod. Nutr. Dev. 44:467-492.

Chilliard, Y., A. Ferlay, J. Rouel, and G. Lamberet. 2003. A review of nutritional and physiological factors affecting goat milk lipid synthesis and lipolysis. J. Dairy Sci. 86:1751-1770.

Institute of Standard and Industrial Research of Iran (ISIRI). 1997. Animal and vegetable fats and oil (methods 4090 and 4091). ISIRI, Karaj, Iran.

Iranian Council of Animal Care. 1995. Guide to the Care and Use of Experimental Animals. Vol. 1. Isfahan University of Technology, Isfahan, Iran.

Kris-Etherton, P. M., and S. Yu. 1997. Individual fatty acid effects on plasma lipids and lipoproteins: Human studies. Am. J. Clin. Nutr. $65: 1628 \mathrm{~S}-1644 \mathrm{~S}$.
Lee, K. W., H. J. Lee, H. Y. Cho, and Y. J. Kim. 2005. Role of conjugated linoleic acid in the prevention of cancer. Crit. Rev. Food Sci. Nutr. 45:135-144.

Luna, P., A. Bach, M. Juarez, and M. A. De La Fuente. 2008. Effect of a diet enriched in whole linseed and sunflower oil on goat milk fatty acid composition and conjugated linoleic acid isomer profile. J. Dairy Sci. 91:20-28.

Mir, Z., L. A. Goonewardene, E. Okine, S. Jaegear, and H. D. Scheer 1999. Effect of feeding canola oil on constituents, conjugated linoleicacid and long chain fatty acids in goats milk. Small Rumin. Res. 33:137-143.

Moon, H. S., H. G. Lee, C. S. Chung, Y. J. Choi, and C. S. Cho. 2008. Physico-chemical modifications of conjugated linoleic acid for ruminal protection and oxidative stability. Nutr. Metab. (Lond.) $5: 16-24$.

National Research Council. 2007. Nutrient Requirements of Small Ruminants: Sheep, Goats, Cervids, and New World Camelids. Natl. Acad. Press, Washington, DC.

Nudda, A., G. Battacone, M. G. Usai, S. Fancellu, and G. Pulina. 2006. Supplementation with extruded linseed cake affects concentrations of conjugated linoleic acid and vaccenic acid in goat milk. J. Dairy Sci. 89:277-282.

Palmquist, D. L., A. L. Lock, K. J. Shingfield, and D. E. Bauman. 2005. Biosynthesis of conjugated linoleic acid in ruminants and humans. Adv. Food Nutr. Res. 50:179-217.

Seeram, N. P., Y. Zhang, J. D. Reed, C. G. Krueger, and J. Vaya 2006. Pomegranate phytochemicals. Pages 3-29 in Pomegranates: Ancient Roots to Modern Medicine. N. P. Seeram, R. N. Schulman, and D. Heber, ed. CRC Press, Taylor \& Francis Group, Boca Raton, FL.

Tsuzuki, T., Y. Kawakami, R. Abe, K. Nakagawa, K. Koba, J. Imamura, T. Iwata, I. Ikeda, and T. Mivazawa. 2006. Conjugated linolenic acid is slowly absorbed in rat intestine, but quickly converted to conjugated linoleic acid. J. Nutr. 136:2153-2159.

Van Soest, P. J., J. B. Robertson, and B. A. Lewis. 1991. Methods of dietary fiber, neutral detergent fiber, and nonstarch polysaccharides in relation to animal nutrition. J. Dairy Sci. 74:3583-3597.

Yamasaki, M., T. Kitagawa, N. Koyanagi, H. Chujo, H. Maeda, J Kohno-Murase, J. Imamura, H. Tachibana, and K. Yamada. 2006. Dietary effect of pomegranate seed oil on immune function and lipid metabolism in mice. Nutrition 22:54-59. 